\title{
A narrative analysis of barriers encountered by a sample of immigrant entrepreneurs in the Eastern Cape province of South Africa
}

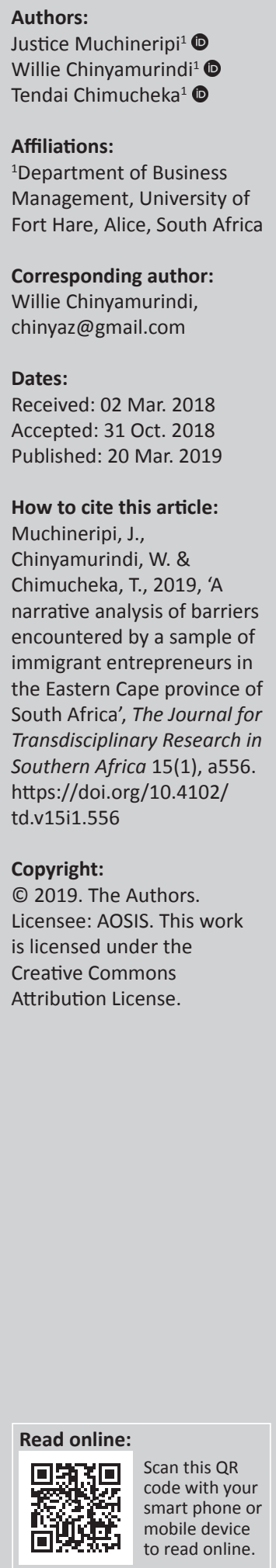

Authors: Willie Chinyamurindi ${ }^{1}$

Affiliations: Management, University of Corresponding author: Willie Chinyamurindi, Dates:

Received: 02 Mar. 2018 Accepted: 31 Oct. 2018 Published: 20 Mar. 2019

this article:

Chimucheka, T., 2019, 'A

narrative analysis of barriers encountered by a sample of South Africa', The Journal for disciplinary Research in https://doi.org/10.4102/

td.v15i1.556

Copyright: Licensee: AOSIS. This work

is licensed under the Creative Commons Attribution License. mobile device
to read online

\begin{abstract}
A growing movement of foreign nationals is settling and starting up businesses in South Africa. Given this fact, there is a need to understand those factors influencing the human capital side of being an immigrant entrepreneur as a basis for coming up with mechanisms to support such a sample group. The focus of this empirical investigation was to understand those barriers that are encountered by immigrant entrepreneurs in the Eastern Cape province of South Africa. To fully experience this, there is a need to understand those factors that affect immigrant entrepreneurship as a practice and the entrepreneur as someone who seeks to enact this value. The narrative research paradigm was adopted to understand the main purpose of the study. Guided by the study objectives, semi-structured interviews were conducted using a sample of foreign immigrants operating businesses in the Eastern Cape $(n=23)$. Individual stories and narratives highlighted the fact that immigrant entrepreneurs encountered the following challenges: financial resources, xenophobia and crime, legislation and finally lack of networks.
\end{abstract}

Keywords: Barriers; Immigrants; Entrepreneur; Entrepreneurship; Narratives; South Africa.

\section{Introduction}

Entrepreneurship is argued to be at the forefront of economic development in both developed and developing countries (Coskun \& Akdere 2017). Entrepreneurship yields positive rewards and upward economic mobility (Wassink \& Hagan 2018). Entrepreneurs also play an important role in the economic growth of a nation and individual communities (Chinyamurindi 2016). According to Welter et al. (2017), entrepreneurs contribute to job growth, innovation and the shaping of communities. In the past years, entrepreneurs have managed to revolutionise entrepreneurship, and it has evolved to become part of globalisation and the boundaryless world. Immigrant entrepreneurship has become one of the popular modes of entrepreneurship and has enabled immigrants to create space to co-exist in their new adopted countries (Griffin \& Olabisi 2017). Globally there has been an increase in the movement of labour not only for social progress but for ideological reasons, often resulting in the start of small businesses (Czaika \& Haas 2014).

South Africa has attracted a lot of foreigners from all over the world; Chiumia (2016) reported that there were an estimated 2.1 million immigrants, as per the 2011 census results. Immigrants have played an important role in shaping South African small, micro- and medium enterprises (SMMEs) (Rambe \& Mpiti 2017). As SMMEs continue searching for new opportunities in the market, survival of these enterprises heavily rely on the innovation of entrepreneurs (Radipere \& Dhliwayo 2014). The immigrant entrepreneurs have become an important driving force in the establishment of new businesses and reducing the escalating South African high rate of unemployment (Fatoki 2014), which according to Statistics South Africa (2017) showed that in the first quarter of 2017, unemployment was at an astounding rate of $27.7 \%$. Therefore, immigrant entrepreneurs, in recent years, have been found to be playing a key role in alleviating unemployment in the communities they operate in (Chimucheka 2014; Fatoki 2014). Kalitanyi and Visser (2010) in their study discovered that over $80 \%$ of the African immigrant entrepreneurs interviewed, engage South African citizens in their business ventures. The number of South Africans who are involved in entrepreneurship has been noted to be dropping since 2013; however, immigrant entrepreneurs have tried to maintain the balance of entrepreneurial ventures in the country by filling the vacuum being left by local entrepreneurs (Global Entrepreneurship Monitor [GEM] 2017). According to the GEM (2014) report cited by Dludla (2015), the percentage of adult South Africans in entrepreneurial businesses has dropped by $34 \%$ from the year 2003 . From a regional perspective, Africa reported the highest established business rates; however, South Africa is reported to have one of the lowest established business rates (GEM 2017). 
A report by the Gordon's Institute of Business Science (2015) stated that the government has not fully recognised the impact that the growth being offered by immigrant entrepreneurship can have on the unemployed youth of South Africa, especially given the necessary support required (Marks 2015). Immigrant entrepreneurs are faced with a number of challenges. The increasing number of immigrants venturing into entrepreneurship has not helped the cause of the immigrant entrepreneurs, but it has escalated the challenges they face. Entrepreneurial business growth is crucial in sustaining economic recovery as it creates jobs (Vorley \& Williams 2017). Research that has been conducted all over the world regarding immigrant entrepreneurship (e.g. Cain \& Spoonley 2013; Kerr \& Kerr 2016; Thechatakerng 2012) has given rise to the recent research in South Africa, including this study to find out the barriers affecting immigrant entrepreneurs' ventures.

\section{Research purpose and objectives}

The purpose of this study was to investigate and understand the barriers encountered by immigrant entrepreneurs in the Eastern Cape province of South Africa. Immigrant entrepreneurs have been part of the business environment in South Africa and have fared reasonably under the circumstances they operate under (Toli 2017). The immigrant operating ground is not level. According to Desiderio (2014), though it can be argued that immigrants have a higher rate of entrepreneurship, it can be noted at the same time their businesses have lower survival rates. Immigrants usually operate in businesses sectors that are neglected by local entrepreneurs (Halkias 2017). Because of the fact that immigrants are said to be more entrepreneurial but usually fail, compared to their local counterparts, this has culminated in the need for having research that investigates challenges that immigrant entrepreneurs encounter (Ghoul 2017). Further, the research applied a different approach in investigating the challenges encountered by immigrant entrepreneurs, as entrepreneurship studies usually adopt a quantitative approach. Hence, there was need to investigate the lived experiences using immigrant entrepreneurs' narratives.

\section{A brief overview of the literature}

In search of ways of surviving in their adoptive country, immigrants in South Africa have resorted to venturing into entrepreneurship (Masocha, Buso \& Fatoki 2017). Considering that venturing into entrepreneurship is difficult under normal circumstances, it can be more difficult by virtue of being a foreigner in South Africa (Lose \& Tengeh 2015). Factors that have been identified by previous researchers as barriers to immigrant entrepreneurs are discussed next.

\section{Education and training}

Education and training are key to the success of entrepreneurs, and immigrant entrepreneurs are not immune to this (Marchand \& Siegal 2015). The GEM (2017) supported this notion by arguing that immigrants are innately entrepreneurs because of circumstances in their native countries, hence the need to have higher levels of education as well as business skills in order to penetrate attractive markets in business. A number of immigrants who do not possess educational and vocational training have been restricted to traditional sectors, which include small-scale retail, snack bars and restaurants because of lack of knowledge (Beckers \& Blumberg 2013). The educational level that is possessed by an immigrant can potentially increase skill and knowledge of being innovative, starting their own businesses and having ways to manoeuvre through challenges (Kruss et al. 2015).

\section{Xenophobia and immigrant entrepreneurship}

Halkias et al. (2015) posited that cultural adaptation, racism and the fear of foreigners pose the greatest threat to the entrepreneurial spirit by immigrants. Xenophobic attacks in South Africa have forced some immigrant entrepreneurs to close their businesses temporarily while some had to close permanently as they could not recover from the losses incurred during the xenophobic attacks (Khosa \& Kalitanyi 2014). Tshishonga (2015) concurred with this notion as he argued that non-South Africans were forced to shut down their businesses and go into hiding. Crush and Ramachandran (2017) highlighted the failure by the relevant authorities to address the problem, as officials have intolerant views indistinguishable from those of ordinary citizens and excuse attacks on immigrant entrepreneurs as unrelated to xenophobia. Khosa and Khaitanyi (2014) found that in Cape Town xenophobia was detrimental to immigrant entrepreneurs' business ventures. Xenophobia can cause major problems to the operations of immigrant entrepreneurs' business ventures, as it leads to loss of income and livelihood (Masocha et al. 2017).

\section{Funding}

Strict adherence to requirements for granting loans by formal financial institutions effectively excludes immigrant entrepreneurs from obtaining access to funding (Tengeh \& Nkem 2017). Immigrant entrepreneurs have cited lack of funding as a major problem in getting their businesses going from the infancy stage (Blz \& Binder 2017). Khosa and Kalitanyi (2014) also acknowledged that for micro-enterprises run by immigrants to access start-up and growth funding, they have to move mountains. Traikova (2017) highlighted that immigrant entrepreneurs face difficulties in accessing funding because of the lack of information on existing financial support programmes to entrepreneurs. Fatoki (2013) found that access to formal debt and equity markets is limited for immigrant entrepreneurs. Crush (2017) pointed out that migrant street traders encounter difficulties in accessing finance and capital necessary to start their entrepreneurial businesses and for daily operations. A study conducted by Garg and Phayane (2014), in terms of the source of start-up capital, found that $100 \%$ of all start-up funding for immigrant entrepreneurs was sourced from their home country. Thus, immigrant entrepreneurs have to adopt various bootstrapping strategies to survive (Bizri 2017). 


\section{Policy and regulation}

Migrant entrepreneurship is increasingly a feature of policyoriented debates in a number of countries that have been receiving a considerable number of immigrants (Ram, Jones \& Villare-Verda 2017). Since independence, the South African government has been trying to devote resources to supporting small enterprises; however, a follow-up survey conducted in 2004 showed that the government had dismally failed to provide assistance to small enterprises (Phillips, Moos \& Nieman 2014). Tengeh and Lapah (2013) pointed out that because of various obstacles, immigrant entrepreneurs need the support of the government. Hence, policymakers may need to develop different sets of policies to support opportunity and necessity entrepreneurship. This clear evidence has significant policy implications nowadays, when many Western governments around the world are facing increasing numbers of immigrants from less developed countries (Nugent 2017). The findings support empirically the claims of human rights organisations that put emphasis on the positive contributions of immigrants (Zelekha 2013).

\section{Criminality as a barrier to immigrant entrepreneurship}

Criminality has affected South African society and immigrant entrepreneurs have not been spared (Chikanda \& Tawodzera 2017). Violence associated with the targeting of foreign shops can best be described as criminality with links to economic competition in the informal economy of South Africa (Piper \& Charman 2012). The main challenge Chinese migrants have to deal with is the high crime rate in South Africa in general, and Johannesburg in particular (Lin 2014). Chinese people consistently refer to Johannesburg as a dangerous place, where it is not safe to walk around at night (Lin 2014). Shopkeepers retold horror stories of fellow immigrant entrepreneurs from neighbouring stores who were severely beaten and robbed, sometimes losing hundreds of thousands of South African rand after just withdrawing money from the bank (Crush \& Tawodzera 2017). Police corruption is also considered normal in South Africa (Barnes, Beaulieu \& Saxton 2017). Police were often described as worse than criminals because Chinese people never felt safe from those who were supposed to protect them and because there was nothing they could do to fight the police (Lin 2014).

\section{Research question}

The overall research question guiding this study was: What barriers influence immigrant entrepreneurs as part of their lived experience of being entrepreneurs?

\section{Research design}

\section{Research approach}

The study falls within the qualitative research paradigm. This approach was adopted to understand not only the factors but also the lived experiences of immigrant entrepreneurs. The narrative research paradigm was used as a method of inquiry in this study as it gives a sense of movement and a coherent sequence of events about an engaged factor in a specific context (Neuman 2011). This approach allows studies to reach their research goals of understanding and interpreting human actions and behaviours (Wiid \& Diggines 2013). Saunders, Lewis and Thornhill (2012) highlighted that qualitative research helps in gaining an understanding of the meaning humans attach to events.

\section{Research methodology and empirical findings}

\section{Sampling and participants}

The study did not set up a predetermined sample size. Interviews were conducted until a point of saturation, which is the point at which responses from participants became similar. In this study saturation was reached at 23 interviews; thus, the sample size is $n=23$. Convenience sampling was utilised in the study as it allowed the researcher to target participants who were conveniently accessible (Teddlie \& Yu 2007). Participants had to be immigrant entrepreneurs. Table 1 summarises the participants' biographical details; pseudonyms were used to protect the identities of the participants.

\section{Data collection methods}

In conducting the study, semi-structured interviews were utilised. Semi-structured interviews were used in this narrative inquiry as they allowed the asking of additional questions from participants in order to explore further their lived experiences. Interviews facilitate the collection of detailed data from their participants with regard to the subject in question of understanding barriers encountered by immigrant entrepreneurs. Before the interview commenced it

TABLE 1: Participant profiles.

\begin{tabular}{|c|c|c|c|c|}
\hline Pseudonym & Gender & Nationality & $\begin{array}{c}\text { Operating } \\
\text { years }\end{array}$ & Business type \\
\hline Blessed & Male & Zimbabwean & 5 & Saloon and taxi business \\
\hline Donald & Male & Nigerian & 7 & Barbershops \\
\hline Olga & Male & Cameroonian & 3 & Training and development services \\
\hline David & Male & Nigerian & 5 & Cleaning services and tree felling \\
\hline Refina & Male & Ghanaian & 2 & Saloons \\
\hline Tadiwa & Male & Zimbabwean & 4 & Computer business \\
\hline Dignity & Male & Zimbabwean & 2 & Web designing and printing \\
\hline John & Male & Zimbabwean & 4 & Buying and selling \\
\hline Eddie & Male & Ghanaian & 6 & Computer shop \\
\hline Sipho & Male & Zimbabwean & 3 & Stationery shop \\
\hline Kuda & Male & Zimbabwean & 2 & Printing and binding \\
\hline Witness & Male & Zimbabwean & 5 & Buying and selling of cars \\
\hline Eve & Male & Nigerian & 6 & Commercial dry cleaning \\
\hline Patrick & Male & Cameroonian & 4 & Tyre business \\
\hline Natasha & Female & Zimbabwean & 8 & Saloons \\
\hline Brian & Male & Zimbabwean & 5 & Shoe retailing \\
\hline Joe & Male & Zimbabwean & 7 & Owns mechanic workshop \\
\hline Josh & Male & Zimbabwean & 2 & Grocery retail shop \\
\hline Donald & Male & Zimbabwean & 1 & Graphic and web design \\
\hline Alex & Male & Cameroonian & 6 & Nightclub \\
\hline Prince & Male & Nigerian & 5 & Buying and selling \\
\hline Bright & Male & Malawian & 3 & Saloons \\
\hline Desmond & Male & Zambian & 3 & Transport business \\
\hline
\end{tabular}


was ensured that the participants were made aware of the purpose of conducting the research and that it was clear to them. The interviews were recorded on audio tapes and transcribed within $24 \mathrm{~h}$ of being recorded; the interviews were typed up on Microsoft Word while the audio tapes of the interviews were being replayed.

\section{Data analysis}

In analysing the data, the researcher followed previous works by other researchers who used narratives in understanding human experiences (Blustein, Kozan \& Connors-Kellgren 2013; Chinyamurindi 2016). What then followed was a procedure to ascertain the three levels of meaning-making. This entailed that firstly the content of each interview was written as a brief piece and then developed into a much longer narrative about each participant. This was accomplished to help develop a good understanding of being an immigrant entrepreneur. Each interview was then reread and the recordings listened to. Chinyamurindi (2016) in his study followed the Labovian narrative analysis, where each narrative is scanned for makers of stories, namely, orientation, abstract, what happened, evaluation and coda (Labov 1972). The rudimentary goal at this point is to enter into the emotion and details, as defined by the storyteller. The type of interrogation is viewed as allowing for key questions to be answered about each (Thornhill, Clare \& May 2004).

\section{Strategies to ensure data quality and reporting}

The study addressed the questions of reliability and validity on the use of narratives to conduct research by using prescribed guidelines (Anney 2014; Leung 2015; Morse 2015). Data was collected over a reasonable time period to avoid fatigue for the researcher. To ensure that all the data was recorded, the interviews were audio taped. After the interview, each audio tape was transcribed within 24 hours. In also trying to ensure data quality, the interviews were conducted in a way that allowed responsiveness and adaptability to changing circumstances, was holistic and had professional immediacy, sensitivity and the ability to clarify and summarise (Guba \& Lincoln 1981).

\section{Findings}

Based on the data analysis, the following five barriers were found as affecting immigrant entrepreneurs: financial access, legislation, networks, xenophobia and crime. In presenting the analysis, participants' stories and narratives were used.

\section{Financial access}

From the stories that were collected during the interviews, financial access was a major impediment to immigrant entrepreneurs' business activities. Some of the participants claimed that some business ideas have died in their embryonic stage because of lack of funding. Immigrants fail to access financial aid from financiers because of their lack of credit history. Capital for starting operating businesses was a major threat to immigrants as it meant there was no way to kick-start their business. The issue of accessing finance also affected some of the participants in securing a place to operate their businesses ventures as landlords ask for cash up front. Besides many business opportunities available in South Africa, Prince had to postpone his plans for opening the business until he had met the financial requirements:

'Mainly the challenge I faced is accessing financial help; especially when I was starting, I needed capital to have a place to operate from. I had to postpone the opening of my business as most doors I knocked were shut for me as a foreigner.' (Prince, male, Nigerian)

In the same way, the problems that Prince faced with start-up capital can also be illustrated in Kuda's narrative, who lamented about start-up capital being a hindrance in starting up his stationery business. He pointed out that as a foreigner your options are limited when it comes to the doors you need to knock on for assistance. For Kuda to raise the muchneeded capital, he resorted to selling his personal belongings and risked losing everything he had worked for.

'The barriers I faced was mainly to do with finance; since my business had to do with printing, the start-up capital to buy the stationery and printing machines was a challenge as a foreign national. I could not access loans from banks or financial institutions; I had to sell some of my belongings to start the business, which was a risk of losing everything I had worked for if the business failed.' (Kuda, male, Zimbabwean)

Sipho's story had a different angle on what he termed as the financial challenge faced by immigrant entrepreneurs. Sipho alluded to the lack of financial incentives offered to immigrant entrepreneurs to keep their business afloat and competitive. He argued that even after you manage to kick-start your business, you still need support systems in order to remain in business, and he feels the South African government has not fully recognised the contribution they bring to the communities they operate in:

'... like now it is difficult for a foreigner to own a business formally and also the environment whereby you try to fund your own business, you cannot find financial incentive from the government whereby they fund foreigners involved in small entrepreneurial activities, whether at start-up or during the operational stage.' (Sipho, male, Zimbabwean)

This quote also introduced a new dimension in the findings. The lack of financial support leads to immigrant entrepreneurs operating their businesses illegally as it becomes expensive for them to do it in a formal way because of lack of support.

Blessed highlighted another aspect of the failed dreams of immigrant entrepreneurs, as their ideas and dreams just die a natural death because the majority of immigrant entrepreneurs cannot raise the money that is required by their businesses:

'The major challenges have been financial; we need a lot of money to start more businesses. We have so many ideas and projects in mind to initiate, but the limitation is capital; we 
cannot get funding from the banks by the virtue of being a foreigner.' (Blessed, male, Zimbabwean)

\section{Xenophobia and crime}

The effects of xenophobia and crime were also ascertained from the participants' narratives. Xenophobia and crime were combined because xenophobic attacks are usually associated with crime. However, the study discovered through interviews with the participants that xenophobia was not as rampant as in other provinces.

For instance, in his interview, Donald narrated that even though he had heard about xenophobia in other provinces here in Eastern Cape, it was not a problem he had faced. What he lamented dealing with was crime:

'... even though they were xenophobic attacks in other cities, this side of the country we never experienced any case as far as I am concerned. From the area I operate from, my main concern is crime as sometimes with the nature of my business we have to close at night. The danger with closing at night is we will attract a lot of criminals due to the fact that we will be carrying cash at the premises.' (Donald, male, Zimbabwean)

In some cases, crime affected the way the business was operated. Typically, immigrants try to operate their business longer than the normal $8 \mathrm{~h}$ but lately there is a need to revert to normal operational hours because of high rate of crime. This resulted in Natasha changing her operating hours as keeping her hair shop open late made her vulnerable to criminal activities.

'I used to open my business until late hours to cater for those who would be at work during the day but would want their hair to be done during the night. They could not get the chance during the day. I stopped opening till late when I was robbed of cash, client's belongings and also the merchandise which was in the hair shop ...' (Natasha, female, Zimbabwean)

Natasha further reiterated that changes in her business trading hours meant loss of possible income from those who did not have time during the day:

'... now due to the high rate of crime we face, it is difficult for me to open my business until late, which has impacted negatively on my income, as it means now all those working-class clients I have been targeting are no longer coming to my saloon.' (Natasha, female, Zimbabwean)

\section{Legislation}

Immigrant entrepreneurs lamented the bureaucratic processes involved in trying to legalise their businesses. These cumbersome bureaucratic processes have forced some of the immigrant entrepreneurs who do not meet the requirements, to operate their business illegally. Immigrant entrepreneurs have reached a level where they hate the process that needs to be followed in order to regularise and legalise their operations. The laws that are in place for the registration of business by foreigners are daunting; thus, many of the immigrants mentioned that they are discouraged from registering their businesses with the responsible authorities. This can be illustrated by Olga's response:

'There are a lot of red tapes when registering your business, which includes the tax; there is too much bureaucracy in South Africa, which makes it difficult for immigrants to register their businesses. Hence, some end up operating illegally.' (Olga, male, Cameroonian)

Other participants corroborated the concerns raised by Olga:

'It is difficult to open a business bank account when you are a holder of a general work permit and it is a challenge to operate without a bank account.' (Blessed, male, Zimbabwe)

'It was not an easy journey to receive an operating licence for my nightclub as the authorities wanted a South African citizenship.' (Alex, male, Zimbabwean)

'Even though the government says there are laws that enable open opportunities to everyone, that is not the case with us small immigrant entrepreneurs; I think it is only open to big foreign investors.' (David, male, Nigerian)

\section{Lack of local networks}

Through participants' narratives it was concluded that in the modern-day business environment as an entrepreneur, there is a need to have networks in the area in which you will be operating. Networking has proven to be a powerful tool to expand a business, as people can exchange ideas as well as getting jobs within the network. Following are participants' response on how the lack of networks have stood as a barrier they encounter in running their businesses.

According to Joe's narrative, it was challenging for him to break into the system and manage to get jobs like anyone else. Joe attributed this to the fact that the businesses he was targeting preferred someone they had worked with previously or who was already in the company's network:

'As a foreigner, it is difficult to do business with established companies as you do not know anyone in their networks.' (Joe, male, Zimbabwean)

Joe's narrative was reiterated by Desmond, who is in the taxi business and who acknowledged that if you are not in their network and they do not know who you are, you pose a threat to them such that some might even conspire to take your life if they feel you will stand in their way:

'It was difficult for me to get my taxi business up and running, as I was constantly told by the taxi bosses: you will not be able to operate in this line of business.' (Desmond, male, Zimbabwean)

Joe's and Desmond's narratives are similar to those of other participants who were in the same scenario as well:

'When I first established my business, I had no one who could network with me with other players in the business; whenever I would try to get prospective clients, as soon as they realise I was a foreigner, they would develop an attitude and the transaction [would] end up not getting through.' (Witness, male, Zimbabwean)

'Bidding for tenders, whether from the private sector or the government, it is always who you know in the system, which 
makes it difficult for me as an immigrant entrepreneur.' (Kuda, male, Zimbabwean)

There was also an interesting dimension to the findings, which was brought forward from the narratives of Desmond and Sipho, which also proved the importance of networking to a business. Both participants incorporated local partners as a way of dealing with the challenge of lack of networks, which proved to be a fruitful move; hence, immigrant entrepreneurs should not take the challenge of networking lightly:

'When I realised the need for networks in the taxi business I decide to incorporate a South African who would act as the owner of the business and from there on my business started running smoothly.' (Desmond, male, Zambian)

'I have gained a lot of networks and I have managed to mingle with many individuals, which have made it possible for me to get jobs and work which used to be difficult to get.' (Sipho, male, Zimbabwean)

\section{Ethical consideration}

Ethical approval (ethical clearance number: CH145SMUC01) was sought from the research ethics committee of the participating institution. The participants were asked to sign an informed consent form, as a way of giving consent to participate in the research voluntarily. Participants were guaranteed confidentiality and anonymity and, in order to help keep their identities anonymous, pseudonyms were used in the research. The participants were also informed of their right to pull out of the interview at any time if they felt uncomfortable.

\section{Discussion}

The main purpose of this study was to investigate the barriers encountered by immigrant entrepreneurs. Operating an entrepreneurial venture has the prospect to change lives; however, that does not come easy, as illustrated in the responses from the participants, who face many challenges. The main factors were discovered to be the barriers affecting immigrant entrepreneurs, including financial access, xenophobia and crime, legislation and lack of networks.

\section{Comparison with previous research}

The issue of difficulties in accessing finance by immigrant entrepreneurs is similar to previous work (Blz \& Binder 2017; Tengeh \& Nkem 2017). Immigrant entrepreneurs bemoaned the challenges they faced when trying to obtain credit lines from formal financial institutions, which is practically impossible as a foreigner. Furthermore, the findings of the study are consistent with the work of Traikova (2017), which suggests that the difficulties in accessing funding by immigrant entrepreneurs are coupled with a lack of knowledge and awareness of existing programmes that can help immigrant entrepreneurs to access financing.

The results of this study align with literature that suggests that the existence of stringent policies and regulation when it comes to legalising immigrant-owned businesses has been a major challenge (Al-Mataani, Wainwright \& Demirel 2017; Phillips et al. 2014). It also emerged from the study that immigrant entrepreneurs have been overlooked by policymakers as potential contributors to the economy. Uniquely in this study, this happens within the Buffalo City Metropolitan Municipality in East London, South Africa where immigrant entrepreneurs bemoan the requirements put in place in order for them to register their businesses; this is a notion that no other studies have explored before. The findings are also in line with the recent work of Ram et al. (2017), which stated that immigrant entrepreneurship has been a feature of policy-oriented debates in a number of countries because of its influence on the local economy.

The findings of this research support some general factors of xenophobic attacks and crime as challenges faced by immigrant entrepreneurs. There is support from previous studies that showed how xenophobia and crime have affected immigrant entrepreneurship (Chikanda \& Tawodzera 2017; Crush \& Ramachandran 2017; Khosa \& Kalitanyi 2014; Lin 2014). In essence, these factors of crime and xenophobia were acknowledged by participants in this study, who stated that crime affected them negatively as it kept them from potential profits. The findings also revealed that in Eastern Cape, attacks cannot be blamed wholly on xenophobia. It emerged from the study that there were criminals who would attack and forcefully take immigrant entrepreneurs' belongings under the disguise of the xenophobic attacks, which were happening around South Africa. The findings concur with a previous study conducted by Crush and Ramachandran (2017), in which South African officials had indistinguishable intolerant views on the attacks on immigrant entrepreneurs as unrelated to xenophobia. Furthermore, the research findings illustrated that because of lack of local networks, it was difficult for the participants to bid for tenders in both the private and public sector. This finding was not identified in earlier literature.

\section{Implications of the study Implication for policymakers}

A clear understanding by policymakers in South Africa of the factors that affect the success and survival of immigrant entrepreneurs can help in coming up with different policies that are not hostile to immigrant entrepreneurs. Immigrant entrepreneurs comprise a population of entrepreneurs that is not being fully engaged and whose economic contribution is not appreciated by policymakers. Participants of the study recommended that policymakers should look into easing the restrictive entry requirements for immigrant entrepreneurs.

The South African government has sought to respond to the needs of skilled immigrants through amending immigration acts that appreciate them as scarce skills (Stern \& Szalontai 2006). However, they have not done much to facilitate the movement of immigrants who want to venture into small businesses. The majority of immigrant entrepreneurs who 
participated in the research bemoaned the bureaucratic process that one has to go through in order to be a legally registered entity. A better understanding of the motivations for immigrant entrepreneurs can help policymakers to design policies that encourage and promote setting up of businesses by immigrants (Radipere \& Dhliwayo 2014).

Policymakers should develop policies towards growing the economy. In the proposed vision 2030 from the National Development Plan, African immigrants should enjoy equal protection to everyone (National Planning Commission 2013). There should be policies that make it easier for local entrepreneurs and immigrant entrepreneurs to co-exist and help each other in moving the economy of South Africa forward. There is a general consensus among scholars that immigrant entrepreneurs help economic development in countries where they set up their businesses; a good example is the USA, which has benefited from immigrant entrepreneurs (Matricano \& Sorrentino 2014). For instance, policymakers can develop synergies between immigrants and local institutions, especially with credit assistance, in order to help immigrant entrepreneurs grow.

South African policymakers can also come up with provisions that create an environment where immigrant entrepreneurs can transfer their knowledge, skills and experience to the locals, as it was identified from the research findings that some of the immigrant entrepreneurs possess skills that are considered to be scarce in South Africa. Policymakers can take advantage of these skills and harness them to the advantage of South African citizens. This can be achieved by awarding jobs to deserving people regardless of nationality and then coming up with a framework that entails an immigrant entrepreneur working with locals and sharing his or her expertise to make it a point of benefit for everyone. A good example is the motor mechanics industry. One immigrant entrepreneur said he had the capacity to train and teach many youths, including those who did not qualify to be enrolled in colleges, to work for themselves.

\section{Implications for immigrants}

The findings of the study have different implications for immigrants who would like to start their own ventures. As an immigrant entrepreneur who wants to start a venture, one has to be prepared for the challenges in setting up a business. Many immigrants establish businesses as an alternative to working in low-wage jobs. A notable characteristic of these immigrant entrepreneurs is their willingness to take risks. They are able to find workers within their immigrant community, often at a lower cost; hence when starting up the business, immigrant business owners are able to minimise costs. As immigrants' presence in entrepreneurial pursuits is becoming increasingly noticeable, there is a need to explore their issues, challenges and business prospects. The study can help immigrant entrepreneurs to understand the types of challenges they should anticipate when starting their business and running the venture. Moutray (2009) argued that immigrant entrepreneurs have to cope with taxes and other regulatory requirements that differ from country to country. The study also helps the immigrants to understand that in order for them to survive or work around challenges they face, they should not always worry about financial success. There is also non-financial business success, which refers to a situation where a business measures its success by other indicators such as the number of employees, efficiency, reputation and perception. This can help immigrant entrepreneurs to be accepted in the communities they operate in, which is important to the survival of their businesses and overcoming challenges.

\section{Limitations}

As with any study, this study also has its limitations. The study was only conducted in the BCM, which makes it difficult for the study to be generalised for the whole country. The research focused on small businesses run by immigrants; hence, the research cannot be generalised to well-established businesses run by immigrant entrepreneurs. The researcher also had difficulties in conducting interviews with immigrants who came from non-English speaking countries, as they would not understand the questions, and thus the researcher only approached those who had knowledge and good command of English. There was also a challenge of participants being sceptical of participating in the research interviews. This is because of fear of being victimised; for instance, some did not have proper documentation for their stay in South Africa.

Future research can be extended to also include immigrant entrepreneurs who are operating at a much bigger scale. Based on the participants' responses, there is a need to conduct research that would pay more attention to women immigrant entrepreneurs. It is also important to conduct research dedicated to the strategies that immigrant entrepreneurs apply to overcome the challenges they face as immigrant entrepreneurs. Future research opportunities could also compare barriers faced by immigrant entrepreneurs and South African entrepreneurs. There is also a need to carry out the research in other parts of South Africa, as this study only focused on BCM.

\section{Conclusion}

Immigrant entrepreneurship is a relatively new, emerging topic in South African. This study sought to understand the lived experiences of immigrants involved in entrepreneurship using the qualitative paradigm. The study managed to elucidate the barriers that immigrant entrepreneurs face in operating their ventures. The study may ignite dialogue between the government and immigrant entrepreneurs on how best they can work together to ease the barriers affecting immigrant entrepreneurs and at the same time also help the South African economy. Besides the barriers immigrant entrepreneurs encounter, it is also important for them to come up with innovative ideas to counter these negative experiences. Such behaviours position them not just as 
victims of negative experiences but as entrepreneurs who can rise above their challenges.

\section{Acknowledgements}

This article was in retrospect, funded by the Govan Mbeki Research and Development Centre (GMRDC) supervisor linked bursaries while researching for master's studies.

\section{Competing interests}

The authors declare that they have no financial or personal relationships that may have inappropriately influenced them in writing this article.

\section{Authors' contribution}

The investigation on which the article reports was carried out by J.M. under the supervision of W.C. and T.C. The report from the research was reworked into an article by J.M., W.C. and T.C.

\section{References}

Al-Mataani, R., Wainwright, T. \& Demirel, P., 2017, 'Hidden entrepreneurs: Informal practices within the formal economy', European Management Review 14, 361-376. https://doi.org/10.1111/emre.12115

Anney, V., 2014, 'Ensuring the quality of the findings of qualitative research: Looking at trustworthiness criteria', Journal of Emerging Trends in Educational Research and Policy Studies 5(2), 272-281.

Barnes, T.D., Beaulieu, E. \& Saxton, G.W., 2017, 'Restoring trust in the police: Why female officers reduce suspicions of corruption', Governance 31(1), 143-161. https://doi.org/10.1111/gove.12281

Beckers, P. \& Blumberg, B., 2013, 'Immigrant entrepreneurship on the move: A longitudinal analysis of first- and second-generation immigrant entrepreneurship in the Netherlands', Entrepreneurship and Regional Development 25(7), 654-691. https://doi.org/10.1080/08985626.2013.808270

Bizri, R.M., 2017, 'Refugee-entrepreneurship: A social capital perspective', Entrepreneurship \& Regional Development 29(9-10), 847-868. https://doi.org/10 $.1080 / 08985626.2017 .1364787$

Blustein, D.L., Kozan, S. \& Connors-Kellgren, A., 2013, 'Unemployment and underemployment: A narrative analysis about loss', Journal of Vocational Behavio 82(3), 256-265. https://doi.org/10.1016/j.jvb.2013.02.005

Blz, F.M. \& Binder, J.K., 2017, 'Sustainable entrepreneurship: A convergent process model', Business Strategy and the Environment 26(1), 1-17. https://doi. org/10.1002/bse.1887

Cain, T. \& Spoonley, P., 2013, Making it work: The mixed embeddedness of immigrant entrepreneurs in New Zealand, Institute for the Study of Labor, Discussion paper series 7332, viewed 20 March 2018, from http://hdl.handle.net/10419/71672

Chikanda, A. \& Tawodzera, G., 2017, Informal entrepreneurship and cross-border trade between Zimbabwe and South Africa, Southern African Migration Programme, Cape Town.

Chimucheka, T., 2014, 'Entrepreneurship education in South Africa', Mediterranean Journal of Social Sciences 5(2), 403-416. https://doi.org/10.5901/mjss.2014. v5n2p403

Chinyamurindi, W.T., 2016, 'A narrative investigation into the meaning and experience of career success: Perspectives from women participants', SA Journal of Huma Resource Management 14(1), 1-11. https://doi.org/10.4102/sajhrm.v14i1.659

Chiumia, S., 2016, African check, fact sheet: How many international migrants are there in South Africa, viewed 13 August 2017, from https://africacheck.org/ factsheets/data-migrants-numbers/

Coskun, A. \& Akdere, M., 2017, 'Exploring leadership development in Turkey: Implications for technology and innovation', in A. Ardivili \& K. Dirani (eds.) Leadership development in emerging market economies, pp. 261-280, Pelgrave Macmillan, New York. https://doi.org/10.1057/978-1-137-58003-0_15

Crush, J., 2017, Informal migrant entrepreneurship and inclusive growth in South Africa, Zimbabwe and Mozambique, Southern African Migration Programme, Cape Town.

Crush, J. \& Ramachandran, S., 2017, Migrant entrepreneurship collective violence and xenophobia in South Africa, Southern African Migration Programme, Cape Town.

Crush, J. \& Tawodzera, G., 2017, Living with Xenophobia: Zimbabwean informal enterprise in South Africa, Southern African Migration Programme, Cape Town.

Czaika, M. \& Haas, H., 2014, 'The globalization of migration: Has the world become more migratory?', International Migration Review 48(2), 283-323. https://doi. org/10.1111/imre.12095
Desiderio, M.V., 2014, Policies to support immigrant entrepreneurship, Migration Policy Institute, Washington, DC.

Dludla, S., 2015, South Africa's entrepreneurship has dropped - Here is why, viewed 15 June 2017, from https://www.smesouthafrica.co.za/South-Africas-entrepreneurshiplevels-have-dropped-heres-why/

Fatoki, O., 2013, 'The determinants of immigrant entrepreneurs' growth expectations in South Africa', Journal of Social Sciences 37(3), 209-216.

Fatoki, O., 2014, 'Immigrant entrepreneurship in South Africa: Current literature and research', Journal of Social Sciences 40(1), 1-7. https://doi.org/10.1080/0971892 3.2014.11893297

Garg, A.K. \& Phayane, N., 2014, 'Impact of small businesses owned by immigrant entrepreneurs on the local community of Brits', Journal of Small Business and Entrepreneurship Development 2(2), 57-85.

Ghoul, W.A., 2017, 'Ethnic and migrant entrepreneurship: The case of Muslim Lebanese entrepreneurs in Dearborn', in V. Ramadan, P. Dana, S. Gerguri-Rashiti \& V. Ratten (eds.), Entrepreneurship and management in an Islamic context, pp. 75-89, Springer, Cham.

Global Entrepreneurship Monitor (GEM), 2014, Global Report 2014, viewed 15 May 2017, from https://www.gemconsortium.org/report/49079

Global Entrepreneurship Monitor (GEM), 2017, 2016/17 Report, viewed 20 August 2017, from https://www.gemconsortium.org/report/49812

Gordon's Institute of Business Science, 2015, State of entrepreneurship in South Africa, viewed 30 August 2017, from http://sablenetwork.com/pdf/The $\% 20$ Entrepreneurial\%20Dialogues $\% 20-\% 20$ State $\% 20$ of $\% 20$ Entrepreneurship $\% 20$ in $\% 20$ South\%20Africa.pdf

Griffin-EL, E.W. \& Olabisi, J., 2017, 'Breaking boundaries: Exploring the process of intersective market activity of immigrant entrepreneurship in the context of high economic inequality', Journal of Management Studies 55(3), 457-485. https:// doi.org/10.1111/joms.12327

Guba, E.G. \& Lincoln, Y.S., 1981, Effective evaluation, Jossey-Bass, San Francisco, CA.

Halkias, D., 2017, Characteristics and business profiles of immigrant-owned small firms: The case of Albanian immigrant entrepreneurs in Greece, viewed 20 January 2018, from https://escholarship.org/uc/item/0983g0w5

Halkias, D., Thuram, P., Harkiolaskis, N. \& Caracatsanis, S., 2015, Female immigrant entrepreneurs, Routledge, New York.

Kalitanyi, V. \& Visser, K., 2010, 'African immigrants in South Africa: Job takers or job creators', South African Journal of Economic and Management Sciences 13(4), creators', South African Journal of Economic and Management Sciences 13 (4), php?script=sci_arttext\&pid=S2222-34362010000400001\&Ing=en\&nrm=iso>

Kerr, S.P. \& Kerr, W.R., 2016, 'Immigrant entrepreneurship', National Bureau of Economic Research, viewed 18 October 2017, from http://www.nber.org/papers/ W22385

Khosa, R.M. \& Kalitanyi, V., 2014, 'Challenges in operating micro-enterprises by African foreign entrepreneurs in Cape Town South Africa', Mediterranean Journal of Social Sciences 5(10), 205-215. https://doi.org/10.5901/mjss.2014.v5n10p205

Kruss, G., McGrath, S., Petersen, I.H. \& Gastrow, M., 2015, 'Higher education and economic development: The importance of building technological capabilities' International Journal of Educational Development 43, 22-31. https://doi. org/10.1016/j.ijedudev.2015.04.011

Labov, W., 1972, Language in the inner city: Studies in the Black English vernacular, vol. 3, University of Pennsylvania Press, Philadelphia.

Leung, L., 2015, 'Validity, reliability, and generalizability in qualitative research', Journal of Family Medicine and Primary Care 4(3), 324-327.

Lin, E., 2014. "'Big Fish in a Small Pond": Chinese Migrant Shopkeepers in South Africa', International Migration Review 48(1), 181-215. https://doi.org/10.1111/ imre.12074

Lose, T. \& Tengeh, R.K., 2015, 'The sustainability and challenges of business incubators in the Western Cape Province, South Africa', Journal of Sustainability $7(10)$ 14344-14357.

Marchand, K. \& Siegal, M., 2015, Immigrant entrepreneurship in cities, International Organization of Migration, Geneva, viewed 20 October 2017 from https://www. Organization of Migration, Geneva, viewed 20 October 2017, from https://www.
iom.int/sites/default/files/our_work/ICP/MPR/WMR-2015-Background-Paperiom.int/sites/default/files/
KMarchand-MSiegel.pdf

Marks, J., 2015, 'The state of entrepreneurship in South Africa', viewed 20 May 2016 from http://www.702.co.za/articles/4179/the-state-of-entrepreneurship-infrom http://w
south-africa

Masocha, R., Buso, B. \& Fatoki, O., 2017, 'Competitive marketing SMMEs in South Africa', Journal of Social Sciences 50(1), 124-132. https://doi.org/10.1080/09718 923.2017.1311727

Matricano, D. \& Sorrentino, M., 2014, 'Ukrainian entrepreneurship in Italy: Factors influencing the creation of ethnic ventures', Journal of Innovation and Entrepreneurship 3(10), 1-28. https://doi.org/10.3390/su71014344

Morse, J.M., 2015, 'Critical analysis of strategies for determining rigor in qualitative inquiry', Qualitative Health Research 25(9), 1212-1222. https://doi. org/10.1177/1049732315588501

Moutray, C., 2009, 'Looking ahead: Opportunities and challenges for entrepreneurship and small business owners', Western. New England. Law Review 31, 763.

National Planning Commission, 2013, National development plan 2030, viewed 15 August 2017, from https://nationalplanningcommission.wordpress.com/thenational-development-plan/

Neuman, L.W., 2011, Social research methods: Qualitative and quantitative approaches, Pearson, Boston, MA. 
Nugent, N., 2017, The government and politics of the European Union, Springer, London.

Phillips, M., Moos, M. \& Nieman, G., 2014, 'The impact of government support initiatives on the growth of female businesses in Tshwane South Africa',
Mediterranean Journal of Social Sciences 5(15), 85-92. https://doi.org/10.5901/ mjss.2014.v5n15p85

Piper, L. \& Charman, A., 2012, 'Xenophobia, criminality and violent entrepreneurship: Violence against Somali shopkeepers in Delft South Cape Town, South Africa', South African Review of Sociology 43(3), 81-105. https://doi.org/10.1080/21528 586.2012 .727550

Radipere, S. \& Dhliwayo, S., 2014, 'The role of gender and education on small business performance in the South African small enterprise sector', Mediterranean Journal of Social Sciences 5(9), 104-110.

Ram, M., Jones, T. \& Villare-Verda, M., 2017, 'Migrant entrepreneurship: Reflections on research and practice', International Small Business Journal 35(1), 3-18. https://doi.org/10.1177/0266242616678051

Rambe, P. \& Mpiti, N., 2017, 'The influence of private and public finance, organisation and environmental variables on the performance of beauty salons in the Free State, South Africa: A theoretical perspective', International Business and Economics Research Journal 16(2), 101-118.

Saunders, M., Lewis, P. \& Thornhill, A., 2012, Research methods for business students, Pearson, Edinburg.

Statistics South Africa, 2017, Quarterly labour force survey, viewed 10 August 2017, from http://www.statssa.gov.za/?p=9960

Stern, M. \& Szalontai, G., 2006, 'Immigration policy in South Africa: Does it make economic sense?', Development Southern Africa 23(01), 123-145. https://doi. org/10.1080/03768350600556380

Teddlie, C. \& Yu, F., 2007, 'Mixed methods sampling: A typology with examples', Journal of Mixed Methods Research 1(1), 77-100. https://doi. org/10.1177/2345678906292430

Tengeh, R.K. \& Lapah, C., 2013, The socio-economic trajectories of migrant street vendors in urban South Africa', Journal of Social Science 4(2), 2039-2117.
Tengeh, R.K. \& Nkem, L., 2017, 'Sustaining immigrant entrepreneurship in South Africa: The role of informal financial associations', Sustainability 9(8), 1-16.

Thechatakerng, P., 2012, 'Thai immigrant entrepreneurs in New Zealand', in V. Khachidze, T. Wang, S. Siddiqui, V. Liu, S. Cappuccio \& A. Lim (eds.), Contemporary research on e-business technology and strategy, pp. 658-670, Springer, Berlin.

Thornhill, H., Clare, L. \& May, R., 2004, 'Escape, enlightenment and endurance: Narratives of recovery from psychosis', Anthropology \& Medicine 11(2), 181-199. https://doi.org/10.1080/13648470410001678677

Toli, L., 2017, 'The identification and exploitation of entrepreneurial opportunities by African immigrants in a selected township in Cape Town', Doctoral dissertation, Cape Peninsula University of Technology.

Traikova, D., 2017, 'Post-socialist informality rural style: Impressions from Bulgaria', in A. Polese, C. Williams, I. Horodnic \& P. Bejakovic (eds.), The Informal Economy in Global Perspective, pp. 141-155, Palgrave Macmillan, Cham.

Tshishonga, N., 2015, 'The impact of xenophobia-Afrophobia on the informal economy in Durban CBD South Africa', The Journal for Trans disciplinary Research in South Africa 11(4), 163-179. https://doi.org/10.4102/td.v11i4.52

Vorley, T. \& Williams, N., 2017, 'Fostering entrepreneurship and economic growth: Pathways to economic resilience in Kosovo', World Review of entrepreneurship, Management and Sustainable Development 13(2), 159-177. https://doi. org/10.1504/WREMSD.2017.10003423

Wassink, J.T. \& Hagan, J.M., 2018, 'A dynamic model of self-employment and socioeconomic mobility among return migrants: The case of urban Mexico', Socia Forces 96(3), 1069-1096. https://doi.org/10.1093/sf/sox095

Welter, F., Baker, T., Audretsch, E. \& Gartner, W.B., 2017, 'Everyday entrepreneurship a call for entrepreneurship research to embrace entrepreneurial diversity', Entrepreneurship Theory and Practice 41(3), 311-321. https://doi.org/10.1111/ etap 12258

Wiid, J. \& Diggines, C., 2013, Marketing research, Juta, Cape Town.

Zelekha, Y., 2013, 'The effects of immigration on entrepreneurship', KYKLOS 66(3), 438-465. https://doi.org/10.1111/kykl.12031 